\title{
The effect of pressure of environmental business and NGO interests on the policy of restricting the EU palm oil import from Indonesia and Malaysia
}

\author{
Henny Triwardani Sopiana , Ali Muhammad, and Zulfan Fakhri Mahendra \\ International Program of International Relations, Faculty of Social and Political Sciences, Universitas \\ Muhammadiyah Yogyakarta, Indonesia, 55183
}

\begin{abstract}
This research will explain how the pressure originating from the interests of business and environmental NGOs in the European Union on the policy of limiting the import of palm oil from Indonesia and Malaysia. As we know, Indonesia and Malaysia are the largest palm oil producing countries in the world and export a lot of their palm oil to the European Union. Recently, the European Union has issued a policy of limiting the import of palm oil for biodiesel products, which policy has been in effect in June 2019. In this policy Limitation of the use of palm oil throughout 2021-2023 will be at the same level in 2019, then its use will be reduced gradually until it runs out in 2030. Business interests and environmental NGOs here have a strong enough influence in the issuance of the policy. This study uses the concept of a Bureaucratic Political Model to answer how pressures from business interests and environmental NGOs influence the policy of import restrictions on palm oil for biodiesel products in the European Union.
\end{abstract}

\section{Introduction}

Indonesia and Malaysia are the largest palm oil producing countries in the world. These two countries in total produce around $80 \%$ of the world's total palm oil production. As the largest palm oil producing country in the world, Indonesia has a $62 \%$ share of palm oil production, while Malaysia is in second place with a 33\% share of palm oil production[1] Indonesia as the largest palm oil producing country in the world, has a plantation area of 12.3 million hectares and production of 35.36 million tons in 2018. Indonesian palm oil plantations are spread across 190 districts to remote areas. These plantations are not only owned by big businessmen, even oil palm is an individual community plantation which is an economic source for the community. Oil palm plantations in Indonesia absorb approximately 16.2 million workers in Indonesia [2]

As the second largest palm oil producer in the world, Malaysia views the palm oil trading sector as very important for the Malaysian economy. Based on data from the

* Corresponding author: triwardani37@,gmail.com 
Malaysia Palm Oil Board, the level of palm oil crude oil production in 2017 reached 19.9 million tons with a planted area of 5.8 million hectares that year. The Malaysian government also established a Malaysian Palm Oil Institute (MPOB) which is a government agency responsible for the promotion and development of the palm oil sector in Malaysia [3]

Indonesia and Malaysia see the growing demand for consumption and market share of palm oil as an opportunity to export. Countries that were the export destinations of Indonesian and Malaysian palm oil in 2018 included India at 6.71 (million tons), the European Union 4.78 (million tons), China 4.41 (million tons), Africa 2.58 (million tons). Million tons), and Pakistan 2.48 (million tons). Palm oil is a leading commodity from the plantation sub-sector whose export performance is influenced by competitiveness and changes in market share that occur in the domestic market and international market [4]

The European Union is one of the trading partner countries for Indonesian and Malaysian palm oil exports. Member countries of the European Union are countries that use a lot of vegetable oil, one of which is palm oil which is used as an ingredient in food, cosmetics and energy fuels. One example of the use of energy fuels is biofuel or biodiesel which uses Crude Palm Oil (CPO) as a mixture. Crude Palm Oil (CPO) is produced by agrarian countries such as Indonesia and Malaysia. CPO exports originating from Indonesia and Malaysia meet the needs of the European Union in addition to Rasepped Oil and Sunflower Oil which are produced by these EU countries. Not only that in the European Union there are also other vegetable oils such as Rapeseed Oil and Sunflower Oil which are the main commodities there. However, Palm Oil is the second most consumed vegetable oil after Prescription Oil in the European Union. The large consumption proves that palm oil is very much needed in the European Union [5]. In addition, the price of palm oil is relatively cheaper than other vegetable oils.

The European Union (EU) government's commitment to the environment is in line with the Kyoto Protocol, which aims to reduce carbon emissions by $20 \%$. Not only that, but also as a form of effort to support the goals of the Community Environment Action Program. Therefore, the European Union issued a policy for biofuels (biodiesel and bioethanol) first known as the Renewable Energy Directive (RED) in 2003. In 2016, the European Union again set new targets in its renewable energy policy, known as (Renewable Energy Directive II) RED II. In RED II, it was determined that the target for the use of renewable energy (biofuels) in 2030 from the initial $27 \%$ rose to $32 \%$ [6].

In early 2017, at the level of the Committee on Environment, Public Health and Food Safety, the European Union voted on policy recommendations to plan to limit the import of palm oil and stop the use of palm oil for biodiesel programs in the European Union in the "Resolution on Palm Oil and Deforestation of Rainforests" in Starsbourg. The policy has then been decided in a plenary session of the European Parliament which recommends the EU Executive Body to execute[7]. The issuance of this policy thus becomes a challenge for the palm oil industry in Indonesia and Malaysia, as it disrupts the two countries' economy and negatively impact their industry and labor sectors [8].

On 22 May 2019 the European Union has set regulations to limit the use of palm oil for the use of Biodiesel or Biofuel (environmentally friendly fuels) in an official EU journal. The regulation restricting the use of CPO products will take effect in June 2019. The limit on the use of palm oil throughout 2021-2023 will be at the same level in 2019. Furthermore, the use of palm oil will be gradually reduced until it is completely exhausted by 2030 .

According to veteran environmentalist Sir Jonathan Porritt, a former chair of the UK government's Sustainable Development Commission, EU policymaking on palm oil can be traced to the efforts of certain lobbying parties in the EU from trade associations or business interests and some environmental NGOs [9]. In this way, the policy regarding 
restrictions on imports of palm oil for biodiesel products by the European Union can be traced through the influence of vegetable oil business interests in the European Union and environmental NGOs.

\section{Theoretical Framework}

In analyzing research on "The Effect of Pressure on Business Interests and Environmental NGOs on the European Union's Palm Oil Import Restriction Policy from Indonesia and Malaysia", the authors use the Bureaucratic Political Model as the concept of this research. According to Graham T Allison, there are three models in describing the process of making foreign policy, namely Rational Actor, Organizational Process, and Bureaucratic Politics. In analyzing the influence of pressure from the EU's vegetable oil business interests and environmental NGOs on the policy of restricting palm oil imports by the European Union, a bureaucratic political model is used to illustrate that foreign policy is seen not as the result of an intellectual process that links goals and means rationally but rather foreign policy is the result of a process of interaction, adjustment and politics among various actors and organizations.

The Bureaucratic Political Model is one of the models in foreign policy. The bureaucratic political model involves various bargaining games (begaining games) between players in the bureaucracy and the national political arena. In other words, foreign policy decision making is a social process, not an intellectual process. In this model describes a process in which each player tries to act rationally, the meaning of the players here is the president, ministers, advisors, generals, parliamentarians etc. They try to set goals, assess alternative means and make choices through an intellectual process. In the bureaucratic politic model, it emphasizes bargaining games as a determinant of foreign policy behavior, in studying the process of making foreign policy decisions, we must obtain information about perceptions, motivations, positions, power, and maneuvers of the players involved in it .In this bureaucratic political model, each political player has their own values which will influence policy recommendations as well. The differences in views and policy recommendations are motivated by the interests of each party, which of course are different.

The picture above is an implementation of a bureaucratic political model regarding the scheme of making policies to limit palm oil imports in the European Union [10]. Where there is the influence of pressure from the European Union's vegetable oil business interests and from environmental NGOs to the European Union government, until finally the European Union government issued a policy of limiting the import of palm oil. If we look at it, which is part of the pressure from the European Union's vegetable oil business interests, there are rapeseed oil and sunflower oil farmers. Then the pressures made by environmental NGOs include those made by FOEE, EFTE, Greenpeace and the Alliance of environmental NGOs.

The European Union itself is not a state but a Supranational International organization with 27 members, but they have a common foreign policy concept and act as actors (like states). The European Union has delegated state powers so that it has authority over member states. Within the European Union, there are many organs that have certain powers. Legislative power is held by the European Council and the European Parliament. The executive power is exercised by the European Commission. These three organs interact with each other and have a balanced power in decision-making in the European Union (Sugito, 2016). 


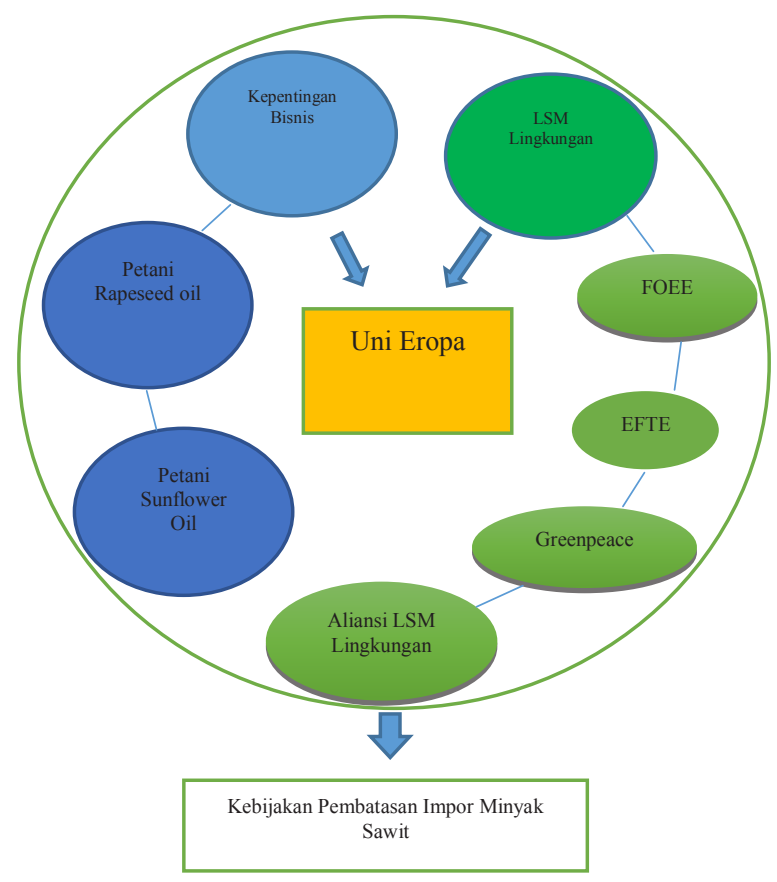

Fig. 1. The Scheme of Policy-Making Restrictions on Palm Oil Imports in the European Union

In the decision-making process in the European Union, the European Parliament (its members are elected directly by European citizens) must approve policies in conjunction with the Council of Ministers (representing the 28 governments of the European Union). Previously, the European Commission proposed initiatives that had previously been reviewed, including assessing the economic, social and environmental consequences that might arise. Through Impact Assessment which determines the advantages and disadvantages of policy choices that may occur. The European Commission then consults with other interested parties such as non-governmental organizations, local governments and representatives of industry and civil society. The draft is then brought to the European Parliament and the Council of Ministers. The European Parliament and the Council of Ministers review the proposals submitted by the European Commission and are authorized to propose amendments. The European Parliament has the power to reject a proposed bill if it does not get the approval of the Council of Ministers, then the conciliation committee will try to find a solution, the Council of Ministers and the European Parliament can reject the legislative proposal at the final reading. However, if both agree on the amendment, the proposed bill can be adopted [11].

\section{Result and Discussion}

\subsection{Pressure from European Union's Vegetable Oil Business Interests Through Demonstration at Oil Refineries in France}

Hundreds of vegetable oil farmers in France who grow sunflower and rapeseed oil crops have called for a nationwide protest at refineries over the approval of palm oil use at Total Energi's La Mede refinery. They took this action on the basis of concerns some French farmers over the entry of cheaper agricultural products. 
On June 10, 2018 in France, farmers of Rapeseed oil and Sunflower Oil have imposed a blockade after the decision by one of the oil refineries in France, "Total", to import cheaper palm oil for its biofuel plant. This move has left farmers feeling dissatisfied with unfair competition. It was a Sunday night when about 100 farmers lined up with tractors and mounds of rubble at the Vatry fuel depot in the Marne region of northeastern France that became the first act of blocking. As of Monday 11 June 2018, a total of about 13 places are being voted on by members of the Federation of the largest agricultural trade unions in France (FNSEA) Fédération nationale des syndicats d'exploitants agricoles (English: National Federation of Agricultural Holders' Unions), which is the boss of the union. that is Christiane Lambert said in an interview with France Info television. Lambert said the blockade was meant to pressure the French government over recently issued trade agreements on imports of palm oil, meat, sugar and ethanol from other countries that it deemed did not respect the same production conditions as French products. The "Total" decision to import palm oil for biofuel refineries is only the last straw, he added.

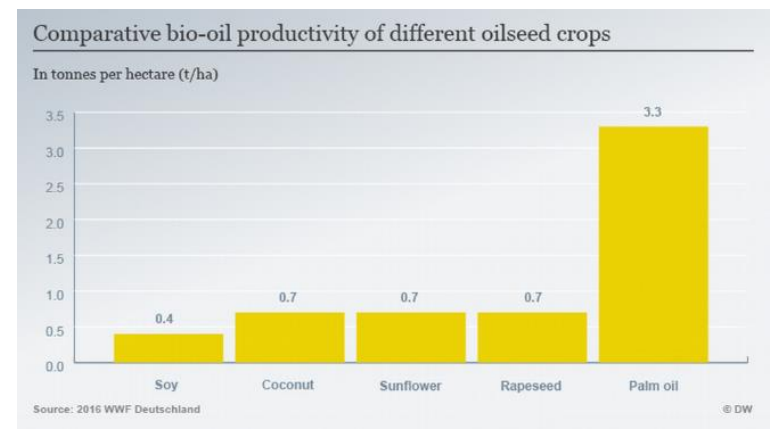

Fig. 2. Comparison of Vegetable Oil Productivity

The French oil and gas company operates about five refineries and nine gasoline depots in France. Which recently invested around $€ 275$ million ( $\$ 324$ million) to turn the refinery at La Mede, in the south of France, into a plant that can produce 500,000 tonnes of biodiesel per year. The company again emphasizes that no more than 50 percent of the raw materials used in the facility are imported palm oil, and that all suppliers are certified by the Roundtable on Sustainable Palm Oil (RSPO). RSPO is a non-profit association founded in 2004 that brings together stakeholders from 7 sectors of the palm oil industry: palm oil producers, processors or traders, consumer goods manufacturers, retailers, banks/investors, and environmental and social non-governmental organizations (NGOs). ), to develop and implement global standards for sustainable palm oil[12].

French farmers are venting their frustration because they want biofuel producers to use local oilseed crops such as rapeseed and sunflower. They have also joined environmentalists in calling for their action to ban oil palm cultivation because it is seen as causing deforestation in Southeast Asia, where most of the world's palm oil is produced. However, in the grouping of vegetable oils, palm oil is cheaper than rapeseed and sunflower oil as biodiesel feedstock. In addition, the relatively high tax rate and strict environmental regulations in the European Union make it difficult for rapeseed and sunflower farmers to compete with palm oil producers. The government does not expect a fuel shortage as a result of the blockade that occurred at the "Total" oil refinery. But the protests at the "Total" oil refinery illustrate the deteriorating relationship between the farmers of the EU's biggest vegetable oil producer and the government of President Emmanuel Macron. 
If seen from the diagram above, it can be clearly seen that the productivity comparison between vegetable oils is in the first place with a much higher productivity level of 3.3 tons per hectare compared to other vegetable oils. Where rapeseed, sunflower and coconut oil are in the range of 0.7 tons per hectare and soybean oil at 0.4 tons per hectare. Many farmers welcomed the president's call for fairer farm prices as part of last year's food chain review. French farmers are the biggest beneficiaries of EU subsidies receiving around $€ 9$ billion a year through direct aid. But FNSEA or France's largest federation of agricultural trade unions estimates that farmers will lose around $€ 5$ billion over the next EU legislature if the cuts are confirmed, exacerbating the loss of competitiveness and growing fears in the rural sector.

Last year, the number of agricultural bankruptcies in France rose to 7 percent. Union president Lambert as union boss attributed it to pressure on agriculture in France that led to price declines on an ongoing basis, coupled with increasing environmental and health norms. The French government is considered to be over-regulated agriculture, where farmers are told to improve quality, standards and use of organic materials and reduce the use of chemicals in crops, but the price they get is not there. As a result, more and more French farmers are suspicious of President Macron, who supports the bloc's trade talks with other countries, such as the Mercosur group of Latin American countries [13].

The EU's specific policy-making on palm oil can be traced through the efforts of certain parties lobbying the EU. Veteran environmentalist Sir Jonathan Porritt, a former chair of the UK government's Sustainable Development Commission, said the EU palm oil boycott was the result of the influence of "two very powerful lobbies," namely, "trade associations seeking to protect EU-based producers." namely rapeseed oil and sunflower oil, as well as several "environmental NGOs" funded by the EU that ultimately support this protectionist agenda, which will be discussed later in Chapter IV of this thesis [9].

Rapeseed oil and sunflower oil are the main vegetable oil commodities in the European Union, both of which meet domestic consumption of vegetable oil. However, the European Union cannot meet the growing growth rate of domestic vegetable oil consumption in the European Union, so that the European Union government has no other choice but to carry out a policy of importing vegetable oil from other countries, one of which is importing palm oil. Palm oil as a competitor to rapeseed oil and sunflower oil has a fairly high level of quality and productivity at a lower price, this is of course a threat to vegetable oil farmers in the European Union. On the other hand, the European Union has made efforts to encourage the growth of domestic vegetable oils, especially Rapeseed Oil (RSO) and Sunflower Oil (SFO). The European Parliament is also facing strong pressure from farmers of Rapeseed Oil (RSO) and Sunflower Oil (SFO) to restore the position of these two commodities to become the dominant commodity in European vegetable oil sources. This then became the concern of European farmers and became an input for the European Parliament to protect their domestic interests.

\subsection{Pressure from environmental NGOs through anti-palm oil campaign actions}

\subsubsection{Friends of the Earth Europe (FOEE)}

As of March 2019, Friends of the Earth Europe (FOEE), which is one of the environmental NGOs in the European Union, has around 5000 local activist groups and more than two million supporters worldwide. FOEE issued a report demanding a ban on palm oil in the European Union. The report is funded by the European Commission's LIFE Program (French: L'Instrument Financier pour l'Environnement) which is the European Union's funding instrument for environmental and climate action. The general objective of LIFE is 
to contribute to the implementation, update and development of European Union environmental and climate policies and laws by co-financing European value-added projects. In 2017, FOEE received nearly 2 million euros from various European Commission institutions. This raises the question of a conflict of interest: how can an NGO provide independent advice to the agency providing critical funding? Many NGOs demanding a full palm oil boycott have similar financial ties to the EU.

In one of the papers released by Friends of the Earth Europe (FOEE) which contains a statement of rejection of the palm oil trade agreement between Indonesia and the European Union in Indonesia - the European Union Comprehensive Economic Partnership Agreement, (IEU-CEPA) which was discussed in Brussels. Where Indonesian negotiators plan to sell their leading commodity to Europe, namely palm oil. However, the FOEE insists on rejecting the inclusion of palm oil into the European Union, stating that there is no palm oil in the EU-Indonesia trade and investment agreement. Accordig to FOEE, palm oil is a commodity that is full of controversy, because it causes various kinds of problems such as labor violations, deforestation and climate change. Friends of the Earth Europe (FOEE) will remain a firm opponent to the inclusion of palm oil in EU trade negotiations[14]

\subsubsection{The European Federation for Transport and Environment (EFTE)}

The European Federation for Transport and Environment (EFTE), which organized a mass petition signed by nearly one million Europeans to promote the ban on palm oil in the European Union, has received more than half a million Euros from the European Commission in 2017. This EFTE also received financial assistance from several institutions including the European Climate Foundation and the Norwegian Development Cooperation Agency, ClimateWorks Foundation, Founders for Fair Trade, The Oak Foundation and many more. The European Federation for Transport and the Environment, commonly referred to as Transport \& Environment (T\&E) is the European umbrella for nongovernmental organizations (NGOs) working in the field of transport and the environment, whose task is to promote sustainable transport in Europe; which means an approach to transportation that is environmentally responsible, economical and socially just. EFTE seeks to fulfill the EU's commitment to climate change in the Paris Agreement through smarter and more ambitious transport policies. Despite being packaged as a proenvironment campaign, by EFTE's own analysis, the EU biofuel industry (which is the main beneficiary of the campaign) still produces more pollution than diesel from fossil fuels (rapeseed is 1.2 times worse, and soybeans is twice as bad) [9].

\section{3,2.3 Greenpeace}

Greenpeace is the largest international non-governmental organization (NGO) in the world that focuses on environmental issues. Greenpeace was founded in 1971, and now has 2.8 million supporters worldwide spread across 41 countries. This global organization receives funding through a variety of direct contributions from individuals estimated at 2.8 million financial backers, as well as from charitable foundations. But they never received funding from the government or corporations. As an international environmental organization, Greenpeace has a very big role in campaigning for environmental issues around the world. In carrying out its actions, Greenpeace adheres to the principle of anti-violent creative confrontation or known as non-coarsion. Creative confrontation actions carried out by Greenpeace in gathering support were through mass mobilization through blockades, banners, propaganda through print media, sabotage, and direct demonstrations taking to the 
streets. The forms of confrontation carried out by greenpeace activists in the rejection of palm oil in the European Union include:

\subsubsection{Greenpeace protests in France}

Greenpeace, an international environmental NGO on October 29, 2019 blocked the entrance of the "Total" oil refinery in southern France, the action was motivated because the "Total" oil refinery used palm oil which was considered controversial by greenpeace activists to produce biofuel. As many as 50 activists, dressed in orange, arrived outside Total's bioref factory in La Mede near Marseille, then they placed two large orange containers in front of the entrance and several protesters chained themselves to prevent vehicles from entering the factory. Greenpeace activists say palm oil causes deforestation, with vast areas of Southeast Asia's rainforest being destroyed or burned in recent decades to make way for plantations. In addition, to release large amounts of greenhouse gases such as carbon dioxide, palm oil threatens the habitat of orangutans and other endangered species.

When it launched its biorefinery (sustainable bioindustry) in La Mede earlier this year "Total" promised to process no more than 300,000 tonnes of palm oil per year, less than half of the total volume of feedstock required and that it would be certified as sustainable according to the standard. EU. Through certification it is certain to reduce deforestation in obtaining palm oil and will result in at least a 50 percent reduction in carbon emissions compared to fossil fuels. France's constitutional court earlier this month rejected Total's offer for tax breaks on the use of palm oil to make biofuels. Last year, legislators excluded palm oil from eligible biofuel inputs for tax breaks[15].

\subsubsection{Various Articles on Anti-Palm Campaign}

Greenpeace is openly campaigning against palm oil and even urging international palm oil buyers to stop buying Indonesian palm oil which is considered to be damaging to the environment. Greenpeace has distributed articles about the ban on the use of palm oil through their official website. As in November 2007, Greenpeace released an article entitled "How the Palm Oil Industry Cooks the Climate". In this article, which contains Greenpeace's accusations against the palm oil industry in Indonesia, they say that the Indonesian palm oil industry has become the cause of Global Warming. Greenpeace also alleged that most of the land for Indonesia's oil palm plantations are developed on peatlands that store a lot of carbon dioxide. They also said the deforestation carried out in clearing land for the palm oil industry in Indonesia had brought Indonesia to the 3rd rank as a producer of greenhouse gas emissions after the United States and China.

Not only that, apart from peatland issues and climate change, the decline in the population of orangutan habitat in Kalimantan is also an accusation by Greenpeace as a result of land clearing for oil palm plantations. He spoke about the declining orangutan population in an article entitled "The Red Traps How Nestlé Using Palm Oil Has A Bad Impact on Rainforests, Climate and Humans in 2010". In the report, Nestle has used palm oil from Sinar Mas which also continues to destroy carbon-rich peat forests and natural forests that are habitat for orangutans.

Not only that, Greenpeace then also published other articles containing their accusations against the palm oil industry in Indonesia. Articles entitled, "Illegal Activities and Forest Destruction of Peatlands in 2009", "Sinar Mas: Palm Oil Threat in 2009", "New EvidenceRainforests and Destruction of Peatlands in 2010", "How Sinar Mas Destroyed the Planet in 2010" , "Climate and Society of Sumatra in 2010" and other articles released by Greenpeace in various national and international media. Greenpeace through its campaigns, either directly or indirectly, will continue to make efforts to save the environment. In 
addition, by using environmental issues, this organization also tries to influence large international companies not to cooperate with palm oil companies from Indonesia [16].

\subsubsection{Greenpeace action on tanker loaded with palm oil}

This incident occurred in November 2018 where the action took place in the waters of the Cadiz bay near Spain, there were about six greenpeace activists from various regions taking action by boarding the tanker "Stolt Tenacity" loaded with palm oil from Indonesia to Europe. The company that ships palm oil from Indonesia is Wilmar International, Wilmar is a major supplier to the international snack giant "Mondelez", which is one of the largest buyers of palm oil in the world, which it uses in many of its most well-known products such as the food product Oreo., Cadbury chocolate and Ritz snacks.

The greenpeace activists staged a peaceful protest by boarding a tanker loaded with palm oil to oppose the destruction of rainforests in Indonesia, unfurling banners reading "Save our rainforests" and "Drop dirty palm oil". Greenpeace is calling on the Mondelez company to bring down the palm oil company Wilmar, until it can prove that its palm oil comes from producers that are not destroying rainforests or exploiting people. An investigation conducted by Greenpeace International found information that palm oil supplier Mondelez destroyed 70,000 hectares of rainforest across Southeast Asia in two years, as well as evidence of child labour, exploitation of workers, illegal logging, forest fires and land grabbing [16]

\subsubsection{Environmental NGO Alliance Campaign}

On November 21, 2019, a coalition of environmental NGOs launched a campaign with the hashtag \#NotInMyTank to oppose deforestation caused by the use of palm oil in biofuels and the cessation of the use of palm oil in biodiesel in the European Union. The campaign took place in front of the EU representative offices in Berlin, Brussels, Lisbon, Madrid, Paris and Rome. The demonstrators carried out their actions by wearing monkey/orangutan costumes, as a form of their concern for the declining orangutan population due to deforestation or deforestation carried out by oil palm plantation companies.

Various coalitions of international environmental NGOs exist in Belgium (Fédération Inter-Environnement Wallonie), Brussels (Transport \& Environment), France (Amis de la Terre and Canopeé), Germany (Deutsche Umwelthilfe and Nabu), Italy (Legambiente), Portugal (Zero ), Spain (Ecologistas en Acción), Sweden (The Swedish Society for Nature Conservation) and the Netherlands (Milieudefensie / Friends of the Earth Netherlands) and many more have issued a petition for the community supported by one of Europe's leading platforms, SumOfUs. Italians and Hungarians expressed the strongest resistance to the use of palm oil in their biofuels at (75\%), followed by France (71\%), the UK (69\%) and Poland (69\%). The survey shows that there is strong public support across Europe against the European Parliament and Member States' decisions to stop using palm oil in diesel fuel [17].

In a pooling of 4,500 Europeans conducted in nine countries, around $82 \%$ of citizens surveyed were unaware that the fuel they were using contained palm oil. When asked whether they would support measures to end policy support and subsidies for palm oil in biodiesel in Europe, 69\% of respondents said they would accept the change, and only around $14 \%$ of respondents opposed it and $16 \%$ had no opinion on the matter. . The demonstrators took action in front of the European Commission building wearing monkey/orangutan costumes, as a form of their concern for the declining orangutan population due to deforestation or deforestation carried out by oil palm plantation companies. 
There are quotes from campaign participants: Rebecca Falcon, Campaign Manager at SumOfUs, said: "Palm oil pumped into gas tanks in Europe is contributing to human rights abuses and the destruction of rainforests across Southeast Asia, pushing thousands of people into in forced labor and pushing species such as the orangutan to the brink of extinction. That's why people across Europe are outraged, and have signed and distributed petitions to expose the EU for its ties to palm oil lobbyists. Together, we demand change from the European Commission; something that is not acceptable."

Ton Sledsens of the Milieudefensie forest campaign in the Netherlands, said: "At the start of the biofuels debate, the Dutch government took a tough stance on high ILUC biofuels that drive deforestation. So Milieudefensie expects the Dutch government to pressure the European Commission and Vice President Timmermans to take firm action against palm oil diesel."

Trees Robijns representative of NABU Germany, said: "Diesel not only pollutes the air we breathe in our cities, it is also mixed with valuable products such as palm oil, fueling deforestation and destroying unique habitats for threatened species such as orangutans. It must stop and we call on the German government to change this dangerous practice."

Sylvain Angerand, French campaign coordinator for Les Amis de la Terre and founder of Canopée, said: "In France new biorefineries are being built to make palm oil biodiesel such as Total in la Mède. Due to this project, the total consumption of palm oil in France can jump up to $60 \%$. It is time for the EU to turn off the tap on palm oil."

Giulio Carini, Senior Campaigner at WeMove.EU said: "More than 500,000 Europeans have signed our coalition petition asking the EU to stop using high-risk fuels like palm oil that destroys our forests and kills orangutans. The European Commission must respect the will of more than half a million Europeans and not bow to pressure from biofuel lobbyists to continue subsidizing palm oil diesel as a "green fuel." According to the demonstrators, the final decision rests with the European Commission which by February 1, should have announced new measures in the use of fuels that are more environmentally friendly and certainly do not cause deforestation [17]

Various kinds of actions have been taken by anti-palm oil environmental NGOs on behalf of the environment both in the European Union and internationally, aiming to urge European governments not to use palm oil as an ingredient in biofuel or biodiesel mixtures in the European Union because it is considered environmentally unfriendly. The policymaking regarding restrictions on palm oil imports issued by the European Union is also the result of the influence of strong lobbies in the European Union government, including from anti-palm oil environmental NGOs that continue to pressure the European government. Various attempts have been made by environmental NGOs to reject palm oil such as holding demonstrations, issuing reports on prosecution of palm oil, blocking actions at oil refineries, peaceful protests on tankers loaded with palm oil, and pressure through the media by distributing articles. Containing the anti-palm oil campaign. Actions against palm oil carried out by anti-palm environmental NGOs have actually been going on for a long time, even this palm issue has become an important focus among environmental NGOs because it is associated with environmental and social problems such as deforestation, child labor, greenhouse gas emissions, habitat destruction. Orangutans, and so on.

\subsection{Palm Oil Import Restriction Policy by Eu}

As we know the European Union is not a state but a supranational international organization, which includes structures, key institutions and distinctive decision-making systems. In contrast to other regional organizations, the European Union has its own character, both intergovernmental and supranationalist. Europeans have put aside the differences, diversity and traditions that exist in each country in favor of the interests of 
solid cooperation. The European Union has brought about fundamental changes in the economic and political functioning of its 27 member states. The European Union as an organization has succeeded in changing the standard of living of its 500 million European citizens and has a direct impact on the lives of its people. In the policy-making process in the European Union, it is necessary to take into account the interests of member states. Not only that, the process of making a policy in the European Union also involves the interests of other parties such as non-governmental organizations (NGOs), private interest groups (bodies representing business, industrial and professional interests), individuals and civil society groups.

There are 3 main institutions involved in EU legislation:

- The European Parliament, which represents EU citizens and is directly elected by them.

- Council of the European Union, which represents the governments of each member state. The Presidency of the Council is divided by the member states on a rotating basis.

- The European Commission, which represents the interests of the Union as a whole.

These three institutions together produce policies and laws through "Ordinary Legislative Procedures" (ex "co-decision") which apply throughout the EU. In principle, the Commission proposes new laws, then Parliament and the Council adopt them. The Commission and member states then implement it, and the Commission is also tasked with ensuring that the law is properly implemented and implemented in all member states [18]

The European Union is the richest capitalist world market region in the world. By building a single market, applying one political power and a single agreement in various fields [19]. The European Union's policy regarding restrictions on palm oil imports is a form of EU foreign policy which is contained in a system of cooperation between EU member countries in every international political relationship, namely the CFSP (Common Foreign and Security Policy). Which involves an intergovernmental decision-making process that depends on the consensus of member states. The image on the next page will explain how the policy-making process in the European Union is carried out by three important institutions in the European Union:

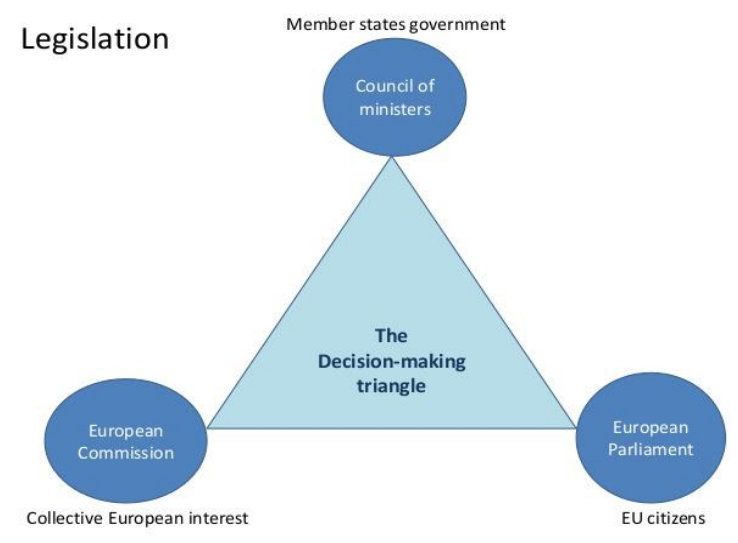

Fig. 3. The Desicion Making Triangle

In its duties, the European Commission as the executive body is responsible for drafting proposals for European legislation which must be presented to Parliament and the Council and carrying out all decisions made by the European Parliament and the Council of Ministers. In drafting the law proposal, other parties such as NGOs, industry and civil society representatives can consult through the public consultation website. Such as the aspirations of the farmers of Rapeseed Oil and Sunflower Oil as well as environmental 
NGOs who want to make a regulation regarding the cessation of the use of palm oil can convey their interests to the European Commission.

After the European Commission drafts a proposal for legislation that concerns the interests of each member state and other interested parties, the draft is brought to the European Parliament and the Council of Ministers. The European Parliament has Legislative powers whose members are directly elected by the representatives of the European Union with a total number of 751 members. While the Council of Ministers is an important institution in decision making, this institution represents the governments of member countries and any EU law or policy must be on the basis of the council's agreement. In principle, the Council of Ministers is ministers who serve in each member country such as the Minister of Finance, Minister of Agriculture, Minister of Foreign Affairs and so on. So, if the problem that is being fixed is the problem of using palm oil products in the European Union, the Minister involved is the Minister of Agriculture or the Minister of the National Environment. The Minister of Agriculture can represent the aspirations of European Union domestic farmers who complain that the use of palm oil will suppress domestic vegetable oils, and the Minister of National Environment represents the aspirations of environmental NGOs who protest against the use of palm oil because it is considered environmentally unfriendly.

Regarding the pressure made by the European Union's vegetable oil business interests and pressure from environmental NGOs, the reasons behind the establishment of a policy to limit the import of palm oil by the EU.

\subsubsection{Policy on Palm Oil Import Restrictions}

On 14 June 2018, the trilogue - namely the European Commission, the European Parliament and the Council of the European Union (which is made up of the Member States of the European Union) - has reached a political agreement to increase the use of renewable energy in Europe. Included in the new regulatory framework is a binding renewable energy target for the European Union of at least $32 \%$ by 2030 compared to $27 \%$ so far, and this percentage may be increased further after a review in 2023. This will enable Europe to maintain its role as a leader in the fight against climate change, in making the transition to green energy and in meeting the goals set out by the Paris Agreement, namely limiting global warming to $2{ }^{\circ} \mathrm{C}$, and achieving a balance between sources and sinks (sink) greenhouse gases in the second half of the century, on an equitable basis, and in the context of sustainable development and efforts to eradicate poverty.

Main achievements, (1) Set a new, binding and renewable energy target for the European Union for 2030 of $32 \%$, including a review clause in 2023 for revisions to increase targets, (2) Improve the design and stability of support schemes for renewable energy, (3) Streamlining and reducing administrative procedures significantly, (4) Establish a clear and stable regulatory framework regarding self-consumption, (5) Increase the level of ambition for the transportation and heating/cooling sectors, (6) Improve and clarify the sustainability of the use of bioenergy, bearing in mind that biofuels should not be made from raw materials obtained from soils with high biodiversity values, such as primary forest and other tree areas, protected areas or grasslands with high biodiversity.

After the political agreement, the text of the Directive must be formally approved by the European Parliament and the Council of the European Union. Once approved by the two legislatures in the coming months, the updated Renewable Energy Directive (RED II) will be published in the Official Journal of the European Union and will enter into force 20 days after publication. EU Member States must take these new elements of RED II and make them part of national legislation no later than 18 months after the date of entry into force [18] 
Then on March 13, 2019, the European Union Commission has determined the criteria for which plants contribute to environmental damage. The European Union Commission said that oil palm cultivation had resulted in excessive deforestation. That's why its use for transportation fuel should be abolished. On 22 May 2019 the European Union has set regulations to limit the use of palm oil for the use of Biodiesel or Biofuel (environmentally friendly fuels) in an official EU journal. Where the regulation restricting the use of CPO products will take effect in June 2019. The limit on the use of palm oil throughout 20212023 will be at the same level in 2019. Furthermore, the use of palm oil will be gradually reduced until it runs out completely in 2030 .

\section{Conclusion}

Indonesia and Malaysia are the two largest palm oil producing countries in the world, accounting for around $80 \%$ of the world's total palm oil production. The European Union is one of the trading partners of palm oil originating from Indonesia and Malaysia, the European Union uses palm oil as a mixture of food, cosmetics and energy fuels such as Biofuel/Biodiesel (environmentally friendly fuel). Then the European Union issued a policy of limiting the import of palm oil for biodiesel products, which was the result of a very strong lobbying influence among several parties in the European Union.

How does the pressure of business interests and environmental NGOs affect the policy of limiting the import of palm oil for biodiesel products in the European Union? In answering the above problems, the author uses the Bureaucratic Political Model to illustrate that foreign policy is seen not as the result of an intellectual process that connects goals and means rationally but that foreign policy is the result of a process of interaction, adjustment and politics between various actors and organizations.

From the research that the author has conducted, it is clear how the pressure exerted by business interests and environmental NGOs on the policy of limiting the import of palm oil. First, the pressure made by vegetable oil business interests in the European Union, namely rapeseed oil and sunflower oil farmers through demonstrations at the "Total" oil refinery on the decision of the oil refinery to import palm oil as biodiesel feedstock. The farmers protested because they wanted to restore the position of Rapeseed Oil \& Sunflower Oil to become the dominant commodity in European vegetable oil sources.

The two environmental NGOs urged the European Union government through an antipalm oil campaign that aims to reject the use of palm oil as a biofuel or biodiesel mixture in the European Union and replace it with a more sustainable and environmentally friendly one. Because the palm oil industry is considered environmentally unfriendly and causes various problems such as deforestation, greenhouse gas emissions, slavery, and the loss of habitat for endangered animals such as orangutans due to the expansion of plantation land, especially in Indonesia and Malaysia, which are dominant palm oil producers. So it can be concluded that business interests and environmental NGOs influence the policy of limiting palm oil imports in the European Union through demonstrations at oil refineries and antipalm oil campaigns that aim to pressure the EU government to stop the use of palm oilbased biodiesel in the European Union.

\section{References}

1. I. Eximbank, Analisa Rantai Pasok (Supply Chain) Komoditas Unggulan Ekspor Indonesia : Minyak Sawit, (2018).

2. Kementerian Pertanian Republik Indoneisa, Outlook Kelapa Sawit 2019, Portal Epublikasi Pertan. (2020). 
3. F. Ibrahim, N. A. A. Osman, J. Usman, and N. A. Kadri, editors , 3rd Kuala Lumpur International Conference on Biomedical Engineering 2006 (Springer Berlin Heidelberg, Berlin, Heidelberg, 2007).

4. G. R. Khairunisa and T. Novianti, J. Agribisnis Indones. 5, 125 (2018).

5. M. Bonita, Jom Fisip 5, 1 (2018).

6. Taufan Adharsyah, Tak Disangka, Gara-gara Ini Uni Eropa Hantam Sawit RI!, CNBC Indones. (2019).

7. Gabungan Pengusaha Kelapa Sawit Indonesia, Resolusi Minyak Sawit Uni Eropa \& Isu Deforestasi - Gabungan Pengusaha Kelapa Sawit Indonesia (GAPKI), Gapki (2017).

8. W. Suwarno, J. Hub. Int. 8, (2019).

9. Youssef Kobo, How the European Union's protectionism is hurting developing economies, Trtworld (2019).

10. N. Azizah, Indones. J. Int. Relations 2, 1 (2018).

11. A. Muhammad, Supranasionalisme Uni Eropa.pdf., (2017).

12. Roundtable on Sustainable Palm Oil, About | RSPO - Roundtable on Sustainable Palm Oil, (n.d.).

13. D.W, French farmers picket Total refineries in palm oil protests | Business | Economy and finance news from a German perspective, (2018).

14. P. De Clerck and Y. Harmono, No palm oil in the EU-Indonesia trade and investment agreement, (2019).

15. RFI, Greenpeace blocks Total's palm oil biorefinery in south of France, (2019).

16. D. T. Sasmi, Int. Islam. High. Educ. Institutions Towar. Glob. Compet. 313 (2018).

17. Transport and Environment, Apes invade EU embassies in European capitals and EU Commission building in Brussels - Campaigning for cleaner transport in Europe | Transport \& Environment, Transportenvironment (2019).

18. European Union, Institutions and bodies | European Union, (n.d.).

19. Peter F Gontha, Kelapa Sawit dan Diskriminasi Uni Eropa, Detik News (2019). 